\title{
POLA KEHILANGAN GIGI DAN KEBUTUHAN PERAWATAN GIGI TIRUAN SEBAGIAN LEPASAN DIKELURAHAN MERAS KECAMATAN BUNAKEN
}

\author{
${ }^{1}$ Trifena L. M. Thio \\ ${ }^{2}$ Christy N. Mintjelungan \\ ${ }^{2}$ Bernat S. P. Hutagalung \\ ${ }^{1}$ Kandidat Skripsi Program Studi Kedokteran Gigi Fakultas Kedokteran \\ Universitas Sam Ratulangi Manado \\ ${ }^{2}$ Program Studi Kedokteran Gigi Fakultas Kedokteran Universitas Sam Ratulangi Manado \\ Email: trifenathio@yahoo.com
}

\begin{abstract}
Loss of tooth among others by a caries and periodontal disease. Missing teeth have a realition with denture, loss of teeth in the long term can lead to pathologic tooth migration experience, alveolar bone loss a missing tooth area, efficiency of mastication up to speech disorders. Making denture to replace missing teeth is important so as to avoid the result of tooth loss. The pattern of tooth loss varies everyone, so the denture care that required in every person who loss their teeth had to be varied. This study aimed to determine the pattern of tooth loss and denture care needs of people in Meras village, Bunaken. The pattern of tooth loss that will be examined are divided partial tooth loss based calsification of Kennedy and complete tooth. This was a cross sectional descriptive study. The sampling method used was purposive sampling with a sample of go people from a population of 646 people. The result showed that tooth loss is greatest in the upper jaw. The most common pattern of tooth loss is partial tooth loss and belonging to the clasification of Kennedy class III (21.1\%). Based on the pattern of tooth loss occurs denture were most needed is a removable partial dentures (71.1\% in the upper jaw and lower jaw $70 \%)$.
\end{abstract}

Keywords: pattern of tooth loss, pertial tooth loss, denture.

\begin{abstract}
Abstrak: Kehilangan gigi antara lain dapat disebabkan oleh karies dan penyakit periodontal. Kehilangan gigi memiliki hubungan dengan gigi tiruan, kehilangan gigi dalam jangka waktu yang lama dapat menyebabkan gigi mengalami migrasi patologis, kehilangan tulang alveolar pada daerah gigi yang hilang, penurunan efisiensi pengunyahan hingga gangguan bicara. Pembuatan gigi tiruan untuk menggantikan gigi yang hilang penting dilakukan sehingga dapat menghindari akibat tersebut. Pola kehilangan gigi setiap orang bervariasi, sehingga perawatan gigi tiruan yang dibutuhkan setiap orang yang kehilangan gigi pun bervariasi. Penelitian ini bertujuan untuk mengetahui pola kehilangan gigi dan kebutuhan perawatan gigi tiruan lepasan di kelurahan Meras kecamatan Bunaken. Pola kehilangan gigi yang diteliti terbagi atas kehilangan gigi sebagian sesuai dengan klasifikasi Kennedy dan kehilangan selurh gigi. Penelitian ini merupakan penelitian deskriptif dengan menggunakan pendekatan cross sectional study. Metode pengambilan sampel yang digunakan yaitu purposive sampling dengan jumlah sampel 90 orang dari jumlah populasi sebanyak 646 orang. Hasil penelitian menunjukkan, kehilangan gigi banyak terjadi pada rahang atas. Pola kehilangan gigi yang paling banyak ditemukan merupakan pola kehilangan gigi sebagian yang tergolong dalam klasifikasi Kennedy kelas III (21,1\%). Berdasarkan pola kehilangan gigi yang terjadi, gigi tiruan yang paling banyak ditemukan merupakan gigi tiruan sebagian lepasan (rahang atas $71,1 \%$ dan rahang bawah $70 \%$ ).
\end{abstract}

Kata kunci: pola kehilangan gigi, kehilangan gigi sebagian, gigi tiruan. 
Seseorang dapat mengalami kehilangan gigi oleh karena berbagai penyebab. Kehilangan gigi antara lain dapat disebabkan oleh karies, penyakit periodontal, trauma dan atrisi yang berat. ${ }^{1}$ Meningkatnya usia sering dihubungkan dengan jumlah kehilangan gigi yang semakin tinggi. ${ }^{2,4}$ Kehilangan gigi juga dapat dihubungkan dengan tingkat pendidikan, dengan tingkat pendidikan yang tinggi, seseorang akan mengetahui serta rutin melakukan perawatan gigi dan mulut. ${ }^{2}$ Kehilangan gigi-geligi dapat menimbulkan berbagai dampak, yaitu dampak fungsional, sistemik dan emosional. ${ }^{8,10}$ Dampak fungsional yaitu berkurangnya kemampuan mengunyah, menggigit serta berbicara. ${ }^{9}$ Dampak sistemik berupa penyakit sistemik seperti defisiensi nutrisi, osteoporosis dan penyakit kardiovaskular, akibat status kesehatan gigigeligi yang buruk dan perubahan pola konsumsi. ${ }^{11,12}$

Pola kehilangan gigi merupakan struktur kehilangan gigi yang diklasifikasikan atas kehilangan gigi sebagian berdasarkan Klasifikasi Kennedy (1925) dan kehilangan seluruh gigi. ${ }^{1}$ Kehilangan gigi sebagian terjadi lebih banyak pada usia dewasa 33-44 tahun, agar tercapai fungsi maksimal gigi-geligi, usia dewasa harus mempunyai paling sedikit 21 gigi di dalam rongga mulut. Penelitian di Washington pada tahun 2004 dan 2006, didapati 5\% dewasa umur 35-44 tahun serta 38\%, populasi berumur 65 tahun keatas mengalami kehilangan 6 elemen gigi atau lebih. ${ }^{2}$

Kehilangan seluruh gigi terjadi lebih banyak pada usia lanjut. Menurut Behavioral Risk Factor Surveillance System (BRFS) pada usia 65 tahun kehilangan seluruh gigi mengalami penurunan dari tahun 1999 yaitu 22\% sampai tahun 2006 yaitu sekitar 15\%. ${ }^{2}$ Perbandingan prevalensi kehilangan gigi-geligi berdasarkan Health Promotion Survey dari tahun 1990 sampai 2003 mengalami penurunan. Populasi usia 65 tahun ke atas yang mengalami kehilangan seluruh gigi sebesar $48 \%$ pada tahun 1990, sedangkan pada tahun 2003 populasi usia 65 tahun keatas yang mengalami kehilangan seluruh gigi sebesar $30 \%{ }^{3}$

Kehilangan gigi memiliki hubungan dengan gigi tiruan, pemilihan jenis gigi tiruan seseorang disesuaikan dengan jumlah elemen gigi yang hilang. ${ }^{5,6}$ Kehilangan gigi dalam jangka waktu yang lama dan tidak segera dibuatkan gigi tiruan dapat menyebabkan antara lain gigi mengalami migrasi patologis, kehilangan tulang alveolar pada daerah gigi yang hilang, penurunan efisiensi pengunyahan hingga gangguan bicara. ${ }^{7}$ Oleh karena itu, pembuatan gigi tiruan sangat penting pada kasus kehilangan gigi.

Kelurahan Meras merupakan kelurahan yang berada di kecamatan Bunaken kota Manado dan berada di lokasi pesisir pantai. Masyarakat kelurahan Meras sebagian besar berprofesi sebagai nelayan, dengan jumlah penduduk 1279 jiwa. Fasilitas kesehatan yang terdapat di kelurahan ini ialah satu Posyandu dan satu Puskesmas pembantu dan tidak terdapat dokter gigi maupun perawat gigi sehingga tidak ada usaha promotif dan preventif mengenai kesehatan gigi dan mulut. Berdasarkan uraian di atas maka peneliti merasa perlu melakukan penelitian mengenai pola kehilangan gigi dan kebutuhan perawatan gigi tiruan lepasan di kelurahan Meras Kecamatan Bunaken.

\section{METODE PENELITIAN}

Jenis penelitian ini merupakan penelitan deskriptif dengan pendekatan cross sectional study. Penelitian ini dilaksanakan di kelurahan Meras kecamatan Bunaken kota Manado pada bulan September 2013Februari 2014. Populasi penelitian ini ialah masyarakat kelurahan Meras kecamatan Bunaken yang berusia 20-65 tahun yang berdasarkan survei awal berjumlah 646 orang. Ukuran sampel minimal diperoleh dengan menggunakan rumus Slovin sebanyak 90. Metode pengambilan sampel dilakukan dengan purposive sampling. Sampel penelitian sesuai dengan ,kriteria inklusi dan eksklusi.

\section{HASIL PENELITIAN}

Kelurahan Meras merupakan salah satu kecamatan di Bunaken kabupaten Minahasa utara. Kelurahan ini berjarak sekitar $30 \mathrm{~km}$ dari kota Manado dan besar kelurahan ini sekitar $\pm 605 \mathrm{H}$ yang meliputi 3 ligkungan. Batas-batas wilayah dari kelurahan Meras yaitu sebelah utara berbatasan dengan gunung Tumpa, sebelah selatan berbatasan dengan teluk Merda, sebelah barat berbatasan dengan kelurahan Tongkaina dan sebelah timur berbatasan dengan kelurahan Molas. Kelurahan Meras merupakan daerah dataran rendah yang sebagian besar wilayah lingkungan berada di pesisir pantai. 
Keadaan penduduk kelurahan Meras kecamatan Bunaken ini terdiri dari beberapa suku yaitu Minahasa, Talaud dan Bantik serta suku lainnya seperti Gorontalo dan Sangihe. Berdasarkan data yang diperoleh kelurahan Meras tahun 2010 jumlah penduduk kelurahan ini mencapai 1279 jiwa yang terdiri dari laki-laki 539 orang dan perempuan 740 orang, dengan terdapat 605 KK. Sebagian besar masyrakat kelurahan Meras berprofesi sebagai nelayan, diikuti dengan petani dan peternak. Sarana pendidikan yang terdapat di kelurahan Meras hanya 1 Sekolah Dasar dan 1 Taman Kanak-kanak, sarana kesehatan juga terdapat di kelurahan ini yaitu 1 Posyandu dan 1 Puskesmas pembantu.

Berdasarkan data diatas menunjukan subjek penelitian pada masyarakat kelurahan Meras kecamatan Bunaken yang terbagi atas pembagian umur mulai dewasa tua yaitu umus 20-39 tahun ada sebanyak 47 orang (52.2\%) dan untuk kelompok umur dewasa tua yaitu umur 40-65 tahun ada sebanyak 43 orang (47.8\%). Distribusi frekuensi subjek penelitian berdasarkan jenis kelamin bahwa dari 90 jumlah subjek penelitian pada masyarakat kelurahan Meras kecamatan Bunaken, didapatkan lebih banyak ditemui subjek penelitian pada perempuan 48 orang (53.3\%) dari pada subjek penelitian pada laki-laki sejumlah 42 (46.7\%).Distribusi frekuensi subjek penelitian berdasarkan tingkat pendidikan

subjek penelitian berdasarka tingkat pendidikan SD paling tinggi yaitu berjumlah 34 orang (37.7\%), SMP 16 orang (17.8\%), SMA 32 orang (35.6\%) dan yang paling sedikit Perguruan tinggi berjumlah 8 orang (8.9\%).

\section{BAHASAN}

Hasil penelitian menunjukan pola kehilangan gigi pada rahang atas paling banyak ditemukan merupakan pola kehilangan gigi sebagian dan yang tergolong dalam klasifikasi kennedy kelas III. Adapun bagian rahang bawah yang paling banyak ditemui mengalami kehilangan gigi bagian daerah posterior dari rahang dimana terdapat gigi-gigi molar. Hal ini dihubungkan berdasarkan pendapat peneliti, gigi posterior akan lebih sulit dijangkau dan dibersihkan sehingga masyarakat sering mengabaikannya, maka dengan mudah gigi-gigi tersebut mengalami karies dan penyakit peiodontal yang mengarah pada kehilangan gigi.

Pola kehilangan gigi di rahang atas, rahang bawah kedua rahang sesuai dengan penelitian terjadi paling banyak pada kelompok umur 20-39 tahun yang termaksud kelompok dewasa muda dan 40-65 tahun dewasa tua. Hal ini sesuai dengan penelitian Prabhu dkk pada tahun 2009 yang menyatakan pada kelompok umur 35-44 tahun, paling tinggi mengalami kehilangan gigi sebagian dan paling banyak kehilangan gigi molar. ${ }^{14}$ Kehilangan seluruh gigi terjadi paling tinggi pada kelompok umur 50 tahun keatas di rahang atas dan rahang bawah, hasil penelitian ini sama dengan penelitian Medina Solis dkk pada tahun 2006 yang menyatakan prevalensi kehilangan gigi pada dewasa muda 2,4\% sedangkan dewasa tua berumur 50 tahun keatas 30,6\%. ${ }^{11}$ Penelitian Lin dkk pada tahun 2001 juga menjelaskan bahwa umur 65 keatas yang mengalami kehilangan seluruh gigi hanya 6\% walaupun giginya masih ada tetapi diindikasikan untuk dicabut. ${ }^{29}$

Hasil penelitian pada masyarakat kelurahan Meras kecamatan Bunaken berdasarkan umur yang dikelompokan umur 20-39 tahun dewasa muda dan dewasa tua 40-65 paling banyak mengalami pola kehilangan gigi sebagian sesuai dengan klasifikasi kennedy kelas IV, diikuti dengan kelas I, kelas IV dan kelas II, hal ini disebabkan gigi posterior pada kedua sisi rahang memiliki fungsi pengunyahan sehingga secara fungisional lebih banyak digunakan dibandingkan dengan bagian anterior. ${ }^{15}$ Pada kelompok umur 50-65 tahun mengalami paling banyak kehilangan seluruh gigi, hasil penelitian ini ditunjang oleh penelitian Lin dkk yang menyatakan lebih dari 90\% yang berusia 60 tahun ke atas telah mengalami kehilangan gigi karena dicabut ataupun indikasi untuk dicabut. ${ }^{29}$ Meningkatnya umur menyebabkan kehilangan gigi, sesuai dengan penelitian Medina dkk menyatakan kehilangan gigi akan semakin banyak pada rongga mulut, hal ini disebabkan adanya karies gigi dan penyakit periodontal yang merupakan alasan hilangnya gigi dimana kedua faktor tersebut akan bertambah parah dengan meningkatnya umur. ${ }^{11}$

Berdasarkan jenis kelamin kehilangan gigi terdapat paling banyak pada perempuan dibandingkan dengan laki-laki disebabkan karena jumlah sampel penelitian banyak ditemui perempuan saat penelitian dilakukan dikarenakan penelitian dilakukan pada hari kerja dan tim peneliti berkunjung kerumah-rumah sehingga banyak dijumpai perempuan yang berprofesi sebagai ibu rumah tangga, sedangkan laki-laki bekerja sebagai nelayan, petani dan peternak, hal ini sesuai dengan penelitian Lin dkk di China pada 
tahun 1989 menemukan perempuan lebih banyak mengalami kehilangan gigi dibandingkan dengan lakilaki disebabkan karena jumlah sampel perempuan lebih tinggi dibanding dengan laki-laki. Pada penelitian Corbet pada tahun 2001 menyatakan bahwa perempuan memiliki sedikit resiko periodontal tetapi besar kemungkinan penyakit karies yang dapat menyebabkan kehilangan gigi. ${ }^{29}$ Berdasarkan klasifikasi penelitian, perempuan paling tinggi mengalami kehilangan gigi sebagian, sesuai dengan penelitian Prabhu dkk tahun 2009 yang meneliti hubungan antara klasifikasi Kennedy dengan jenis kelamin di penelitiannya terlihat jumlah perempuan paling tinggi pada semua klasifikasi Kennedy juga menunjukan adanya hubungan yang signifikan antara jenis kelamin dengan klasifikasi Kennedy. ${ }^{14}$ Hasil penelitian Prabhu dkk pada tahun 2009 menyatakan bahwa perempuan mempunyai tingkat pendidikan dan tingkat pekerjaan yang lebih rendah sehingga dalam segi keuangan perempuan sangat bergantung pada laki-laki hal ini mungkin menjadi alasan kehilangan gigi pada perempuan lebih tinggi. ${ }^{1}$

Ditinjau berdasarkan tingkat pendidikan, hasil yang ada meperlihatkan kehilangan gigi sebagian paling banyak didapati paling banyak pada kelompok SD, disebabkan karena masyarakat di kelurahan Meras ini pada umumnya memiliki tingkat sosial yang rendah sehingga tidak mampu mendapatkan pendidikan yang lebih tinggi, diikuti SMP, SMA dan paling sedikit ialah perguruan tinggi (PT). Penelitian ini sesuai dengan penelitian Esan dkk yang menyatakan bahwa tingkat pendidikan membawa pengaruh pada suatu penduduk. Seseorang dengan tingkat pendidikan yang tinggi cenderung memiliki informasi yang cukup mengenai cara memelihara kesehatan gigi dengan baik dibandingkan dengan seseorang dengan tingkat pendidikan yang rendah, hal tersebut memungkinkan seseorang dengan tingkat pendidikan tinggi memiliki penghasilan yang tinggi akan memiliki kesadaran untuk memelihara dan memperbaiki kesehatan gigi dan rongga mulut dan melakukan perawatan gigi dan mulut. ${ }^{1}$ Data dari Behavioral Risk Factor Survalliance System (BRFSS) pada tahun 2004-2006 menunjukan populasi yang mengalami kehilangan 6 gigi atau lebih dengan pendidikan SD, SMP atau SMA dan tidak bersekolah yaitu 23\%, sedangkan perguruan tinggi hanya $15 \%{ }^{2}$

Berdasarkan pola kehilangan gigi yang dialami oleh masyarakat kelurahan Meras ditentukan gigi tiruan yang dibutuhkan. Pada penelitian Mukatash tahun 2010 menyatakan bahwa kesadaran pasien dalam kebutuhan untuk menggunakan gigi tiruan lebih sedikit dibandingkan kebutuhan yang seharusnya. ${ }^{23}$ Sesuai dengan penelitian kebutuhan gigi tiruan bervariasi setiap individu, gigi tiruan sebagian lepasan paling banyak dibutuhkan oleh masyarakat kelurahan Meras kecamatan Bunaken yaitu untuk rahang atas sebanyak 64 orang (94.1\%) dan rahang bawah sebanyak 63 (90\%) merupakan GTSL serta dibutuhkan juga GTP sebanyak 4 (5.9\%) untuk rahang atas dan 7 (10\%) untuk rahang bawah. Hasil penelitian ini menyatakan GTSL paling banyak dibutuhkan oleh karena jumlah kehilangan gigi sebagian yang tinggi pada kelas I, kelas II, kelas III dan k elas IV sesuai klasifikasi Kennedy yang kehilangan beberapa gigi dan kasus kehilangan gigi dengan rentang yang panjang. ${ }^{27}$ GTP paling sedikit ditemukan ,menurut penelitian Hutton dkk terjadi penurunan kehilangan seluruh gigi yang menyebabkan penurunan penggunaan GTP. ${ }^{16,17}$ Sebegian besar masyarakat telah menyadari bahwa gigi asli dapat dipertahankan selama hidup. Adanya upaya pencegahan, bahan restorasi yang lebih baik pada perawatan menyebabkan terjadinya penurunan insiden kehilangan seluruh gigi. Adanya upaya pencegahan, bahan restorasi yang lebih baik pada perawatan konservasi dan endodontik menyebabkan terjadinya insiden kehilangan gigi.

\section{SIMPULAN}

1. Pola kehilangan gigi sebagian paling banyak ditemukan sesuai klasifikasi Kennedy kelas III untuk rahang atas dan kelas I untuk rahang bawah. Kehilangan gigi paling banyak ditemukan pada kelompok dewasa muda umur 20-39 tahun sebanyak 47 orang (54.5\%). Pola kehilangan gigi yang paling banyak ditemukan berjenis kelamin perempuan sebanyak 48 orang (53.3\%) dan kehilangan gigi yang paling banyak terjadi pada tingkat pendidikan SD sebanyak 34 orang (37.7\%).

2. Gigi tiruan yang paling banyak dibutuhkan sesuai dengan pola kehilangan gigi yang dialami yaitu GTSL 


\section{DAFTAR PUSTAKA}

1. Esan TA, Olusile AO, Akeredolu PA, Esan AO. Socio-demographic factors and edentulism the Nigerian experience. BMC Oral Health 2004; 4(3): p:1-6.

2. Washington State Department of Health. Oral health. Januari 2008. Available from: http://www.doh.wa.gov/cfh/oral-health/ ( 9 September 2009 ).

3. Millar WJ, Locker D. Edentulism and denture use. Health Reports 2005; 17(1): p:55-8.

4. Vargas CM, Kramarow EA, Yellowitz JA. The oral health of older Americans. Aging trends(3). National Center for Health Statistics, 2001: p:1-8.

5. Hartono R, Kosasih A, Hidayat H, dkk. Estetik \& prostetik mutakhir. Jakarta: EGC, 1992: h:4

6. Teofilo LT, Leles CR. Patients' self-perceived impacts and prosthodontic needs at the time and after tooth loss. Braz Dent J 2007; 18(2); p:91-6.

7. Battisttuzzi PGFCM, Kayser AF, Keltjens HMAM, Plasmana PJJM. Gigi tiruan sebagian titik tolak pada diagnosa dan perawatan gigi-geligi yang rusak. Alih bahasa A I Kosasih, A R Kosasih. Editor Susianti Kentjana, Lilian Yuwono. Jakarta: Widya Medika,1996. H, h:1-9

8. Jones JA, Orner MB, Spiro A, Kressin NR. Tooth loss and dentures: patients' perspectives. Int Dent J 2003; 53: p:327-34.

9. Allen PF, McMillan AS. A review of the functional and psychosocial outcomes of edentulousness treated with complete replacement dentures. J Can Dent Assoc 2003; 69(10); p:662.

10. McMillan AS, Wong MCM. Emotional effect of tooth loss in community-dwelling elderly people in Hong Kong. Int J Prosthodont 2004; 17(2): p:172-6.

11. Medina-Solis CE, Perez-Nunez R, Maupome G, Casanova-Rosado JF. Edentulism among Mexican adults aged 35 years and older and associated factors. Am J Public Health 2006; 96(9): p:1578-81.

12. Bernard ML, Thomas KL, Edward CL, Mok WH, Eric CM. Pattern of tooth loss in young Hongkong adults: a preliminary study based on Prince Philip Dental Hospital Patients in 1984, 1998 and 2004. HKDJ 2007; 4: p:22-7.

13. Gunandi A Hariyanto, Margo Anton, Burhan KL, Suryatenggara F, Setiabudi I.Buku Ajar Ilmu Geligi Tiruan Sebagian Lepasan. Jilid 1. Penerbit Hipokrates. 1991. h: 22-3

14. Prabhu N, Kumar S, D’souza M, Hegde V. Partial edentulousness in a rural population based on Kennedy's classification: An epidemiological study.J Prosthodont 2009; 9: 18-23. http://www.cabdirect.org/abstracts/20093184715.html;sessionid=32F4F818A259491963AF33BD 5286835C

15. Indonesian e-dental Information. Kehilangan gigi. Januari 2009. Available from: http://www.geocities.com/sjuhada/kehilangangigi.html (12 April 2010). 